\title{
The Effect of Using Cokriging against Ordinary Kriging When Estimating Phosphate Deposits at Elsebaiya Area, Egypt
}

\author{
H. A. Farag ${ }^{1 *}$, M. A. Gouda², M. A. Yassin² \\ ${ }^{1}$ Mining and Petroleum Engineering Department, Faculty of Engineering, Al-Azhar University, Cairo, Egypt \\ ${ }^{2}$ Mining Engineering, Mining and Petroleum Engineering Department, Faculty of Engineering, Al-Azhar University, Cairo, Egypt \\ Email: `hussinfarag@yahoo.com, magouda2005@yahoo.com, m_a.yassien@yahoo.com
}

How to cite this paper: Farag, H.A., Gouda, M.A. and Yassin, M.A. (2020) The Effect of Using Cokriging against Ordinary Kriging When Estimating Phosphate Deposits at Elsebaiya Area, Egypt. World Journal of Engineering and Technology, 8, 700-711. https://doi.org/10.4236/wjet.2020.84050

Received: October 4, 2020

Accepted: November 6, 2020

Published: November 9, 2020

Copyright $\odot 2020$ by author(s) and Scientific Research Publishing Inc. This work is licensed under the Creative Commons Attribution International License (CC BY 4.0).

http://creativecommons.org/licenses/by/4.0/

\begin{abstract}
Application of geostatistical techniques when evaluating mineral deposits could reflect some geological characteristics which help through the stage of planning and production. In the present study, an attempt has been done on two phosphate deposits at Elsebaiya area on both sides of the River Nile namely: Um Tondoba mine at Elsebaiya East area and Western River Nile mine in Elsebaiya West area. Depending on the available data, statistical analysis illustrated differences in the distribution of $\mathrm{P}_{2} \mathrm{O}_{5} \%$ and ore thickness within the studied areas. Geostatistics used to start with constructing variograms for $\mathrm{P}_{2} \mathrm{O}_{5} \%$ and thickness for the two phosphate deposits to be used with ordinary kriging models, also constructing cross variograms between $\mathrm{P}_{2} \mathrm{O}_{5} \%$ and thickness to be used with cokriging models where the difference in the variogram parameters reflected a specific variation for each deposit horizontally and vertically. The ordinary kriging models and cokriging models illustrated different distribution behavior through both the two kriging techniques.
\end{abstract}

\section{Keywords \\ Ordinary Kriging, Cross Variogram, Cokriging, Elsebaiya}

\section{Introduction}

Elsebaiya area has long attracted the attention of many geologists because of the presence of economic phosphorite deposits. The phosphate rocks are part of the Vast Upper Cretaceous marine phosphorite basin which is used as a source of phosphorus for fertilizers, and for manufacture of phosphoric acid and other chemicals [1]. 
The Egyptian phosphorite bearing rocks are geographically widely distributed as thin shallow marine deposits [2] [3].

The phosphate occurrences in Egypt, from North to South, may be subdivided into three East-West trending facies belts, Northern facies belt, Central facies belt and Southern facies belt [4]. The phosphorite of the Central facies belt represents the most economic occurrences and was confined to the following localities, the Red Sea coast from Safaga to Quseir, the Nile Valley between Idfu and Qena and the Western Desert on Abu Tartour Plateau.

In this study, both ordinary kriging and cokriging methods were applied to investigate their precision on mapping the distribution of $\mathrm{P}_{2} \mathrm{O}_{5} \%$ and thickness. So it may be possible to gain a clear picture of the distribution at the studied areas.

Statistical analysis starts with constructing of histograms and calculates their parameters such as: minimum, maximum, range, mean, standard deviation, variance, skewness, kurtosis, and coefficient of variations to illustrate the distribution of $\mathrm{P}_{2} \mathrm{O}_{5} \%$ and thickness within the deposit while geostatistical analysis is used for modeling them in both sides of the River Nile in Elsebaiya area, Nile Valley, Egypt by using GS+ software.

Experimental variogram and cross variogram were constructed for two variables to characterize the spatial variability of the measured $\mathrm{P}_{2} \mathrm{O}_{5} \%$ and thickness values depending on the available data. These data are $\mathrm{X}$ and $\mathrm{Y}$ coordinates, $\mathrm{P}_{2} \mathrm{O}_{5} \%$ and ore thickness for each sample location.

Depending on the parameters of the variogram and cross variogram models of two variables, a comparison between ordinary kriging and cokriging techniques was used to present distribution model of $\mathrm{P}_{2} \mathrm{O}_{5} \%$ which could be used in mine planning and production.

\section{Description of the Studied Areas}

\subsection{Location}

Phosphate deposits are distributed in several locations in the Nile Valley. The studied areas are Um Tondoba mine in Elsebaiya East area and Western River Nile mine in Elsebaiya West area as shown in Figure 1. Um Tondoba mine is located between latitudes $25^{\circ} 06^{\prime}-25^{\circ} 15^{\prime} \mathrm{N}$ and longitudes $32^{\circ} 44^{\prime}-33^{\circ} 06^{\prime} \mathrm{E}$ while Western River Nile mine is located between latitudes $25^{\circ} 05^{\prime}-25^{\circ} 14^{\prime} \mathrm{N}$ and longitudes $31^{\circ} 30^{\prime}-32^{\circ} 10^{\prime} \mathrm{E}$.

\subsection{Stratigraphic}

Ignoring the geology of the ore deposits is the most common source of errors when evaluating and producing them. Geostatistical evaluation of any ore body should be built on the basis of studying its geologic setting [5]. It is possible to create a computer model from borehole data, but this model is meaningless if it is not compatible with the geologist's understanding. The studied area is characterized by the presence of Upper Cretaceous - Paleogene succession which is 


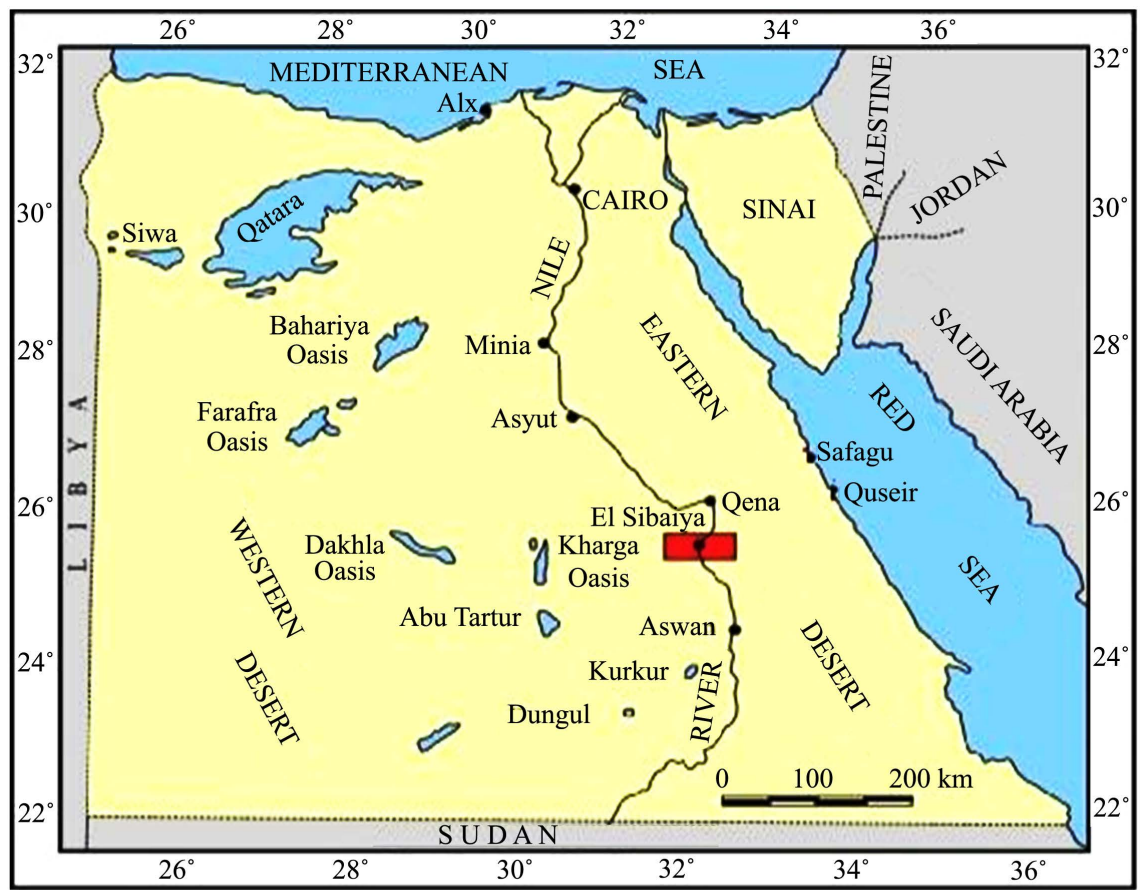

The studied area

Figure 1. Location map of the studied areas.

considered as one of the most important geologic successions that have long been subjected to detailed geological studies either in Nile Valley or generally in Egypt.

In the studied areas, Duwi Formation consists of differed successive layers for the two areas as shown in Figure 2. The phosphate of this formation can be classified into two horizons where the bottom one represents the high economic phosphorite bed in Elsebaiya East area where it has largest thickness and high phosphorus content while in Elsebaiya West area, phosphate located as economic in two members (lower and upper from base to top) [6] [7].

\section{Methodology}

\subsection{Variography}

A variogram is a graph illustrating the average variability between samples and the distance between them. The variogram can be described as the variation in values among samples some distance apart as a measure of their spatial correlation [8].

The characterization of phosphate ore deposits has been carried out through variograms.

The variogram function summaries the spatial continuity for all possible pairings of data for all lag distances $h$ as:

$$
(h)=\frac{1}{2 N(h)} \sum_{N(h)}[g(x)-g(x+h)]^{2}
$$




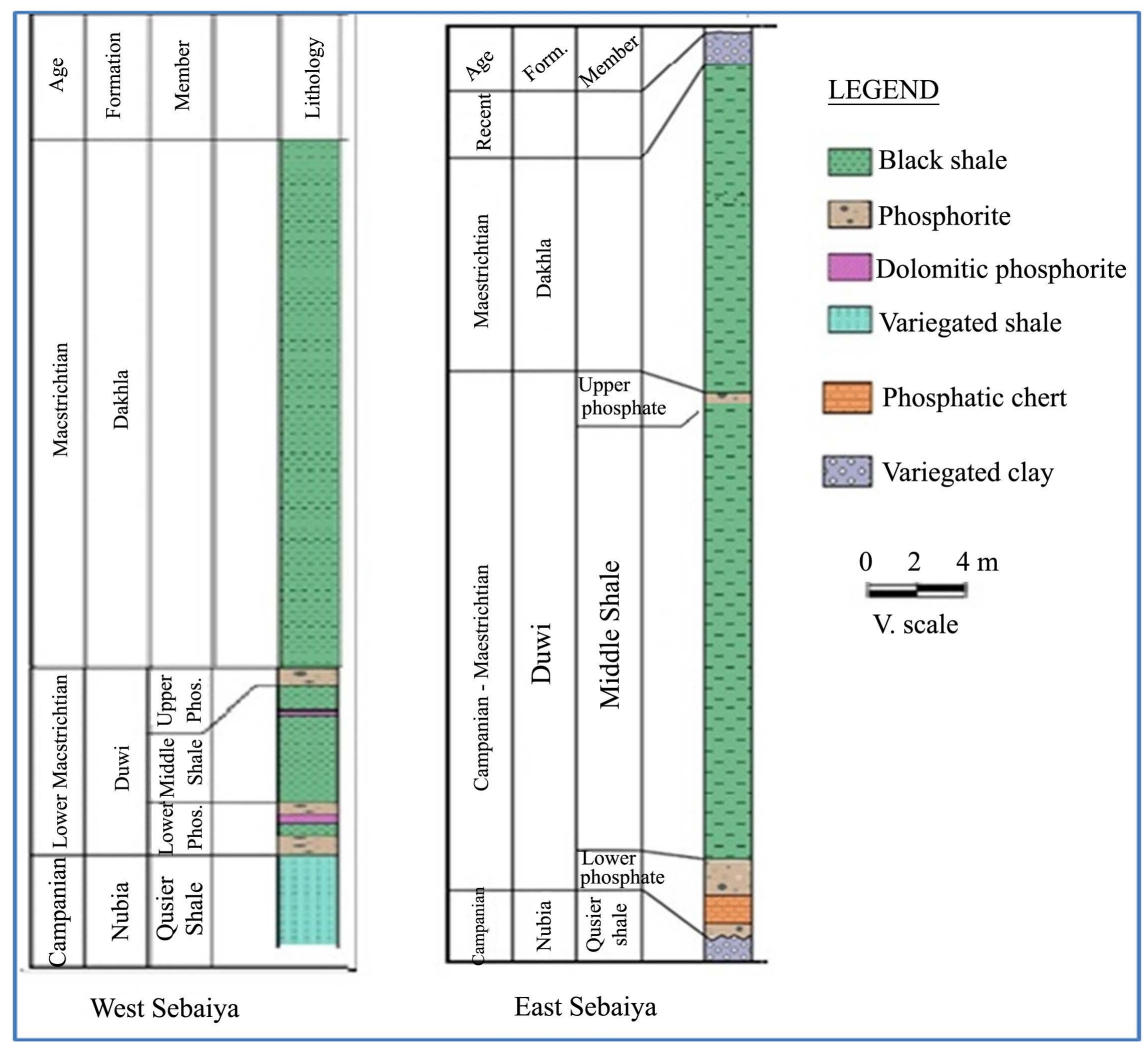

Figure 2. Lithostratigraphic succession in the studied area.

where $g(x)$ represents the value of any variable at location $\mathrm{x}$ and let $g(x+h)$ represent the value of the same variable at $h$ distance. The variogram is a function describing half of the expected squared differences between $g(x)$ and $g(x+$ h).

For cokriging analysis, the cross variogram should be determined by the following equation [8].

$$
\gamma(h)=\frac{1}{2 N(h)} \sum_{N(h)}[g u(x)-g u(x+h)][g v(x)-g v(x+h)]
$$

where $u$ and $v$ are the primary and covariate variables, respectively.

The variogram as a tool for structural analysis of the ore body reflects many parameters to represent characteristics of the studied regionalized variables, these parameters are: sill $(C)$, nugget effect $\left(C_{0}\right)$ and range of influence (a).as shown in Figure 3.

\subsection{Kriging}

\subsubsection{Ordinary Kriging Method}

Kriging is a geostatistical technique that is used to interpolate a surface from a scattered set of known points (X, Y plots) in which a continuous surface of values can be predicted between the known locations [9].

Ordinary kriging, which allows the mean of the measurements to vary spatially, was used in this study. The different parameters obtained from variograms 


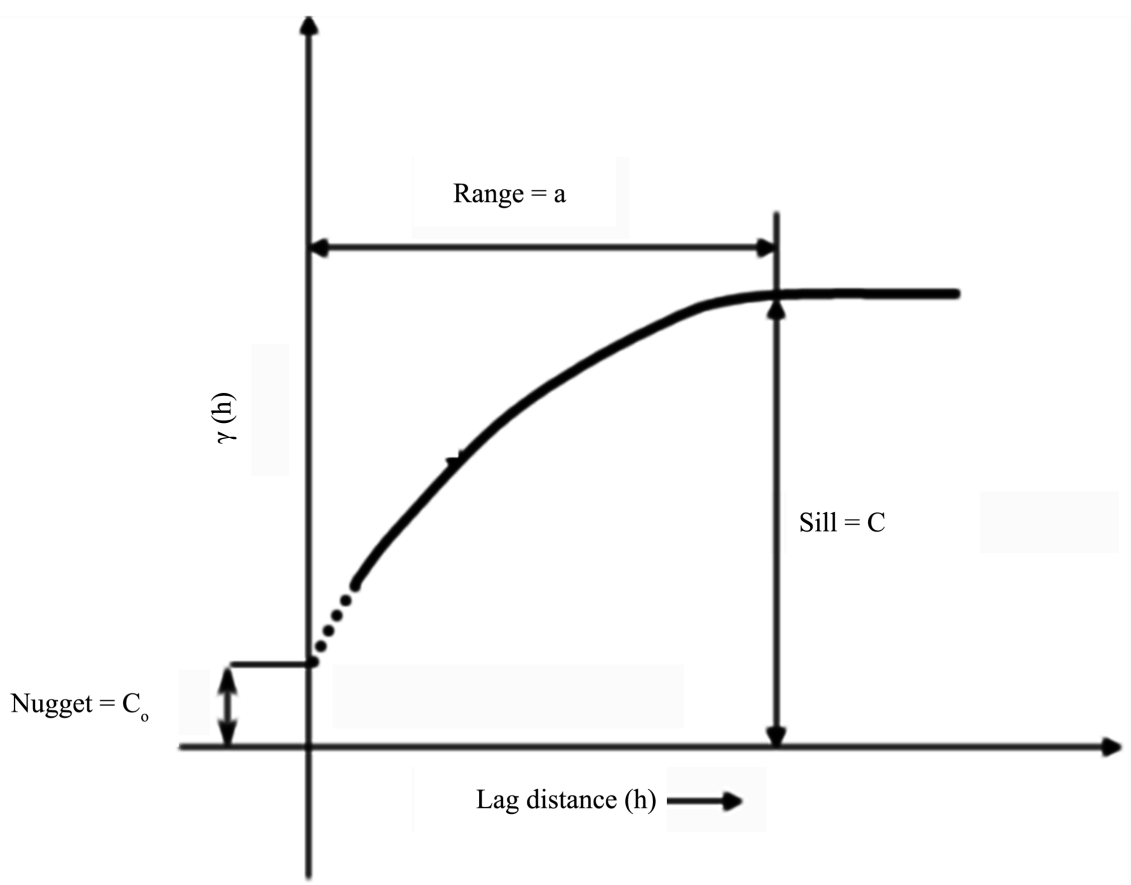

Figure 3. Variogram parameters.

were used to calculated sample property values based on weighting values assigned to sample values in nearby locations. The Ordinary kriging prediction $Z\left(x_{0}\right)$, is defined as:

$$
\underset{o k}{\dot{Z}}\left(x_{0}\right)=\sum_{n=1}^{n} \lambda_{a}^{o k} Z\left(x_{a}\right)
$$

With the constraint that the weights, Ordinary kriging, sum to 1 to ensure an unbiased prediction:

$$
\sum_{n=1}^{n} \lambda_{a}^{o k}=1
$$

where $Z\left(x_{0}\right)$ is the estimated value at location $x, Z\left(x_{a}\right)$ is the known value at location $X_{a}, \lambda_{a}$ is the weight associated with the data.

\subsubsection{Cokriging Method}

Cokriging is an interpolation technique that allows one to better estimate map values if the distribution of a secondary variate is known. The secondary variate (also called a covariate or Z2) is sampled from the same locations as the primary variate $\mathrm{Z}$, and also from a number of additional locations. If the primary variate is difficult or expensive to measure, then cokriging can greatly improve interpolation estimates without having to more intensely sample the primary variate [10]. The kriging estimate is based not only on distance to nearby sample locations for $\mathrm{Z}$ and the variogram for $\mathrm{Z}$, but also distance to nearby sample locations for $\mathrm{Z} 2$, the variogram for $\mathrm{Z} 2$, and the cross variogram for $\mathrm{Z} 1$ and $\mathrm{Z} 2$. This can provide a more robust estimate of $Z$ at unsampled locations if $Z 1$ and $Z 2$ are sufficiently correlated. 


\section{Available Data}

The present study was carried out at Phosphate Deposits on Both Sides of the River Nile in Elsebaiya Area, Egypt. The available data for the present study is based on sampling information derived from the location as shown in Figure 4 and Figure 5. The data used in this studied areas were obtained from Elnasr Mining Company. These data include technical report about mining works and site surveying map for the studied areas. Both ordinary kriging and cokriging techniques were used to achieve a goal of this study.

\section{Conventional Statistical Analysis}

The statistical analyses have been performed on two variables, $\mathrm{P}_{2} \mathrm{O}_{5} \%$ and ore thickness, which gives the distribution of them and the standard parameters of statistics. Table 1 gives the summary statistics of the data sets for two variables at the studied areas. Figure 6 and Figure 7 shows the histograms of variables

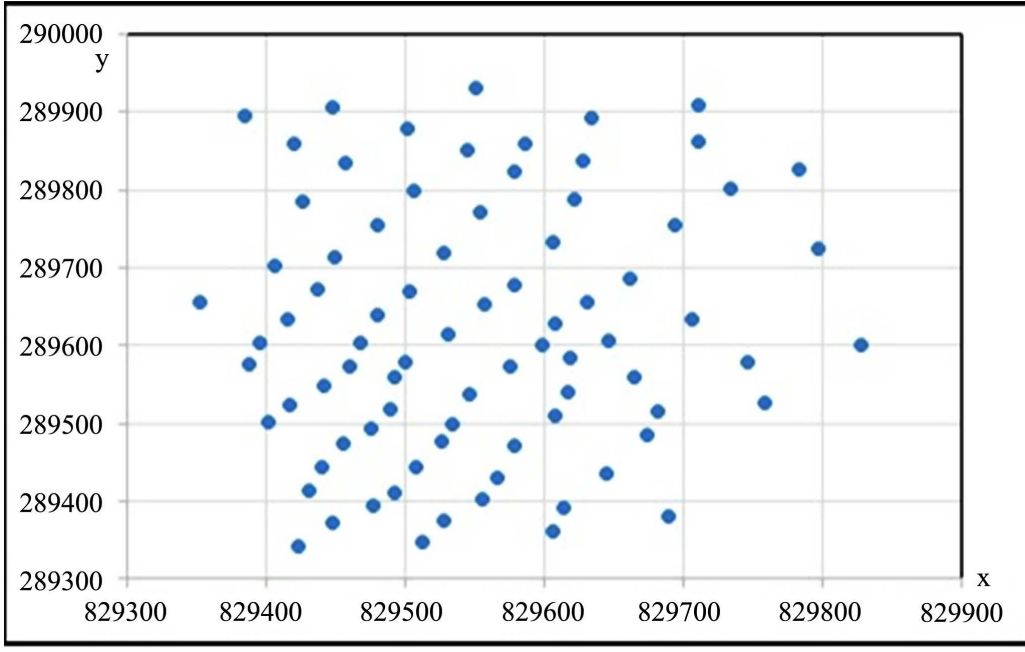

Figure 4. Scatter plot of bore holes at east Sebaiya.

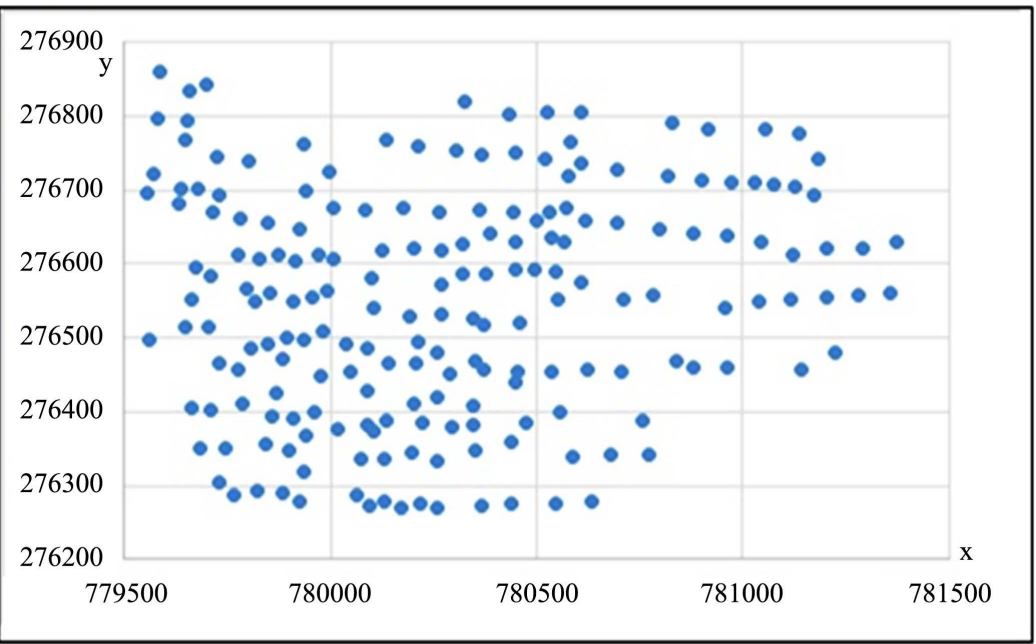

Figure 5. Scatter plot of bore holes at west Sebaiya. 


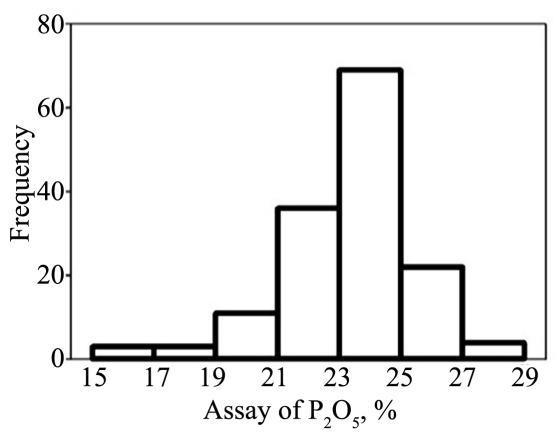

(a)

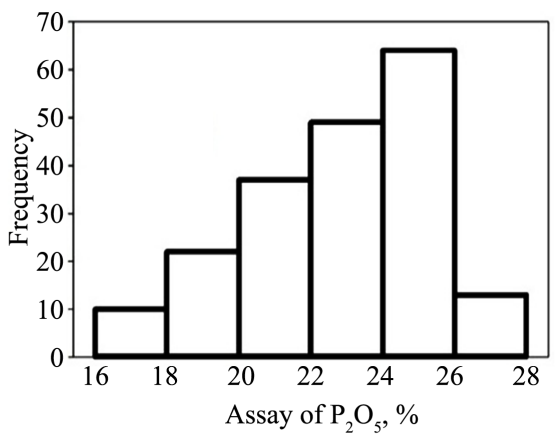

(b)

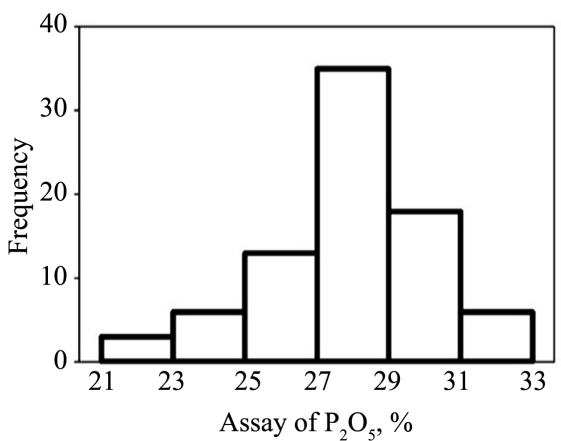

(c)

Figure 6. Histograms of $\mathrm{P}_{2} \mathrm{O}_{5} \%$ in the studied areas where, (a) Lower member of west sebaiya, (b) Upper member of west Sebaiya and (c) Um Tondoba mine in east Sebaiya.

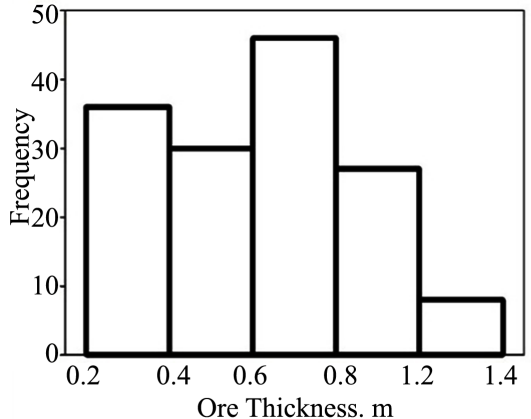

(a)

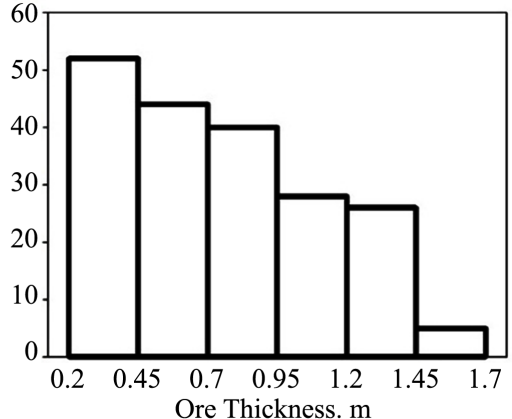

(b)

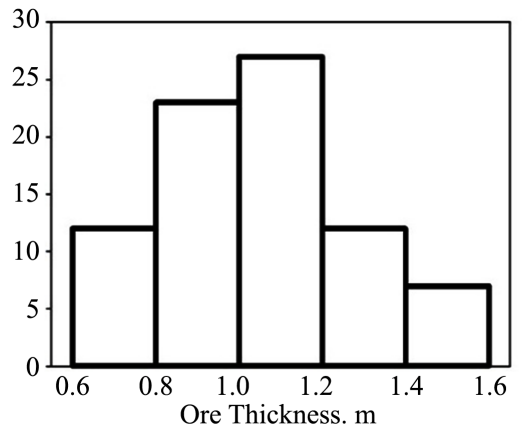

(c)

Figure 7. Histograms of ore thickness in the studied areas where, (a) Lower member of west sebaiya, (b) upper member of west Sebaiya and (c) Um Tondoba mine in east Sebaiya. 
Table 1. Statistical parameters of two variables in the studied areas.

\begin{tabular}{cccccccc}
\hline \multirow{2}{*}{$\begin{array}{c}\text { Statistical } \\
\text { Parameters }\end{array}$} & \multicolumn{3}{c}{$\mathrm{P}_{2} \mathrm{O}_{5}, \%$} & \multicolumn{3}{c}{ Thickness, $\mathrm{m}$} \\
\cline { 2 - 3 } \cline { 5 - 6 } & Lower & Upper & East & Lower & Upper & East \\
\cline { 2 - 3 } Min. & 15.72 & 16.6 & 22.78 & 0.2 & 0.2 & 0.7 \\
Max. & 28.5 & 27.5 & 32.43 & 1.4 & 1.7 & 1.5 \\
Mean & 23.44 & 22.74 & 28.28 & 0.71 & 0.75 & 1.06 \\
Variance & 3.72 & 5.24 & 3.18 & 0.08 & 0.12 & 0.03 \\
Stan. deviation & 1.93 & 2.29 & 1.78 & 0.27 & 0.35 & 0.17 \\
Range & 12.78 & 10.9 & 9.65 & 1.2 & 1.5 & 0.8 \\
Co. of variation & 0.08 & 0.1 & 0.06 & 0.39 & 0.47 & 0.16 \\
Skewness & -0.97 & -0.51 & -0.63 & 0.16 & 0.49 & 0.32 \\
Kurtosis & 5.31 & 2.6 & 3.9 & 2.39 & 2.48 & 2.81 \\
\hline
\end{tabular}

that constructed for studied areas. The results show that the $\mathrm{P}_{2} \mathrm{O}_{5} \%$ distribution is negatively skewed of all studied areas otherwise the distribution is positively skewed of the thickness at all studied areas. On the other hand, coefficient of variation values is the lowest in East Sebaiya for $\mathrm{P}_{2} \mathrm{O}_{5} \%$ and thickness which shows a significant change in variables within the ore body. The higher range of $\mathrm{P}_{2} \mathrm{O}_{5} \%$ occurs in the lower member of West Sebaiya, while the higher range for thickness occurs in the upper member.

\section{Construction of Variograms}

Depending on the available data for each variable, isotropic variograms and crossvariograms were constructed and fitted to a suitable model as shown in Figures 8-10. The variogram parameters for $\mathrm{P}_{2} \mathrm{O}_{5} \%$ and thickness in the studied areas were summarized in Table.

As shown from the variogram models in Figures 8-10 and geostatistical parameters in Table 2 it is clear that $\mathrm{P}_{2} \mathrm{O}_{5} \%$ distribution is characterized by the presence of nugget effect in the Lower Member of West Sebaiya and this is expected to the presence of intercalated within the deposits while in the Upper Member of West Sebaiya and Um Tondoba Mine in East Sebaiya, it is clear that high continuity in $\mathrm{P}_{2} \mathrm{O}_{5}$ \% distribution while in thickness distribution the higher continuity occurs at the Western part of Sebaiya than the Eastern side. The cross variogram obtained strong spatial dependence of variables properties at all studied areas.

The screen effect ratio can be regarded as a criterion to classify the spatial dependence of phosphate properties. If the ratio is less than $25 \%$, the variable has strong spatial dependence, between $25 \%$ and $75 \%$, the variable has moderate spatial dependence and more than $75 \%$, the variable shows weak spatial dependence [11] [12]. 


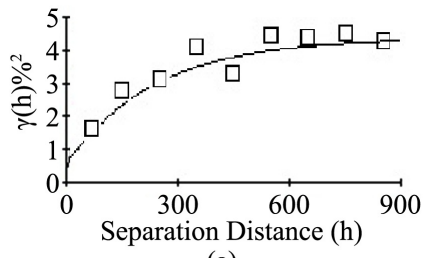

(a)

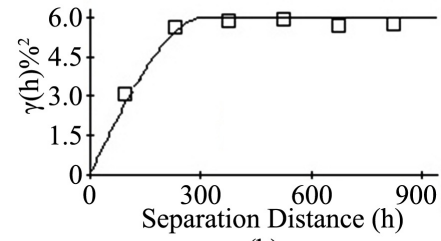

(b)

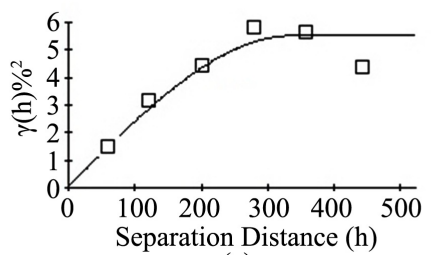

(c)

Figure 8. Variogram model for $\mathrm{P}_{2} \mathrm{O}_{5} \%$ in the studied areas where, (a) lower member of west Sebaiya, (b) Upper member of west Sebaiya and (c) Um Tondoba mine in east Sebaiya.

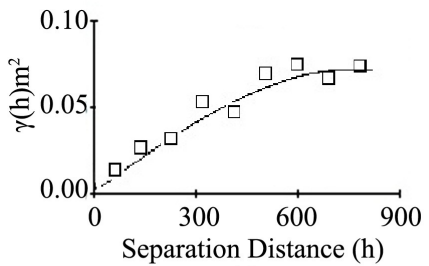

(a)

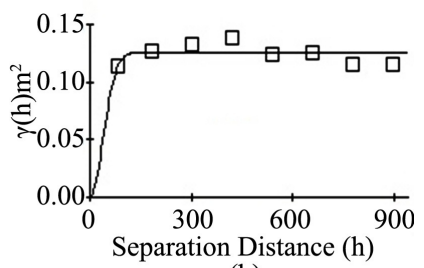

(b)

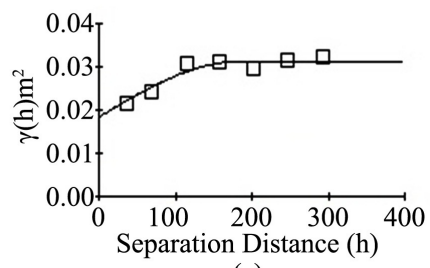

(c)

Figure 9. Variogram model for ore thickness in the studied areas where, (a) lower member of west Sebaiya, (b) Upper member of west Sebaiya and (c) Um Tondoba mine in east Sebaiya.

Table 2. Variogram and cross variogram parameters of two variables in the studied areas.

\begin{tabular}{|c|c|c|c|c|c|c|c|c|c|}
\hline \multirow{3}{*}{$\begin{array}{l}\text { Variogram } \\
\text { parameters }\end{array}$} & \multicolumn{3}{|c|}{$\mathrm{P}_{2} \mathrm{O}_{5} \%$} & \multicolumn{3}{|c|}{ Thickness } & \multicolumn{3}{|c|}{ Cross Variogram } \\
\hline & \multicolumn{2}{|c|}{ West } & \multirow{2}{*}{ East } & \multicolumn{2}{|c|}{ West } & \multirow{2}{*}{ East } & \multicolumn{2}{|c|}{ West } & \multirow{2}{*}{ East } \\
\hline & Lower & Upper & & Lower & Upper & & Lower & Upper & \\
\hline Type & Gauss. & Sph. & Sph. & Sph. & Sph. & Sph. & Expon. & Gauss. & Gauss. \\
\hline Direction & Global & Global & Global & Global & Global & Global & Global & Global & Global \\
\hline Range, $m$ & 705 & 310 & 338 & 814 & 222 & 225 & 596 & 237 & 530 \\
\hline $\begin{array}{l}\text { Nugget effect } \\
\qquad\left(\mathrm{C}_{0}\right)\end{array}$ & 0.52 & 0.0 & 0.0 & 0.0 & 0.0 & 0.02 & 0.0 & 0.0 & -0.03 \\
\hline Sill (C) & 3.77 & 5.9 & 5.5 & 0.08 & 0.13 & 0.03 & 0.03 & 0.09 & -0.16 \\
\hline $\begin{array}{c}\text { Screen Effect } \\
\text { Ratio } \mathrm{C}_{0} / \mathrm{C}\end{array}$ & 0.14 & 0.0 & 0.0 & 0.0 & 0.0 & 0.67 & 0.0 & 0.0 & 0.19 \\
\hline
\end{tabular}




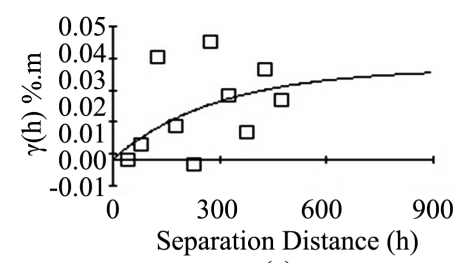

(a)

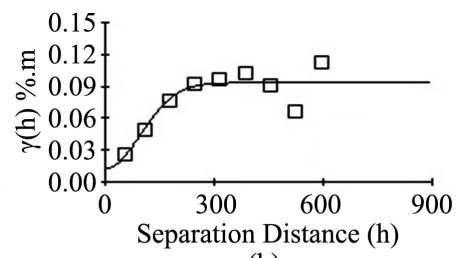

(b)

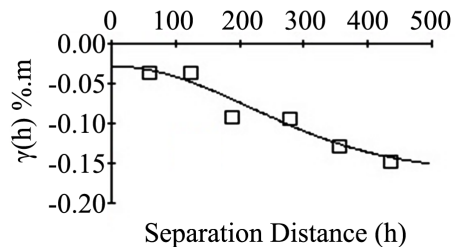

(c)

Figure 10. Cross variogram model between assay and thickness in the studied areas where, (a) Lower member of west Sebaiya, (b) Upper member of west Sebaiya and (c) Um Tondoba mine in East Sebaiya.

\section{Spatial Prediction}

Both Ordinary Kriging and Cokriging techniques were used to interpolate the unknown locations by creating map analysis that showing the distribution of $\mathrm{P}_{2} \mathrm{O}_{5} \%$ in the studied areas as shown in Figures 11-13. These maps are classified into classes, each class represents specific percentage of $\mathrm{P}_{2} \mathrm{O}_{5} \%$ colured with specific colur, which helps in showing the distribution in different locations at the studied areas. The Ordinary Kriging maps indicate that the $\mathrm{P}_{2} \mathrm{O}_{5} \%$ tend to be increased closed to middle part of the Lower Member of West Sebaiya where the phosphate medium grade $(24 \%-26 \%)$ is the dominant ratio and the high grade value of $\mathrm{P}_{2} \mathrm{O}_{5} \%$ disappears.

While in the Upper Member of West Sebaiya the low grade value of $\mathrm{P}_{2} \mathrm{O}_{5} \%$ appears and the phosphate medium grade $(21 \%-23 \%)$ is the dominant ratio which increases northward.

Also, it is clear from these models the majority of yellow and red colures which high grade value of $\mathrm{P}_{2} \mathrm{O}_{5} \%$ appears $(27 \%$ - 32\%) at the Eastern part of Elsebaiya area which tend to be increased to the South-East direction. While the Cokriging technique indicates clear different in $\mathrm{P}_{2} \mathrm{O}_{5} \%$ distribution along all studied areas where some parts of the studied areas turned to a lower concentration part of $\mathrm{P}_{2} \mathrm{O}_{5} \%$ content and others to a higher concentration of $\mathrm{P}_{2} \mathrm{O}_{5} \%$ content as shown in cokriging distribution maps. This information will assist mining engineers to take appropriate decisions during exploitation stage.

\section{Conclusions}

In this research, ordinary kriging and cokriging methods were used to spatial estimation of $\mathrm{P}_{2} \mathrm{O}_{5} \%$ in phosphate deposits at Elsebaiya area.

Statistical analysis reflects the clear difference between the distributions and statistical parameters of phosphate within the studied areas. The appearance of high coefficients of variation values at the Upper Member of Western Sebaiya in $\mathrm{P}_{2} \mathrm{O}_{5} \%$ and thickness is due to the high variability of them. 


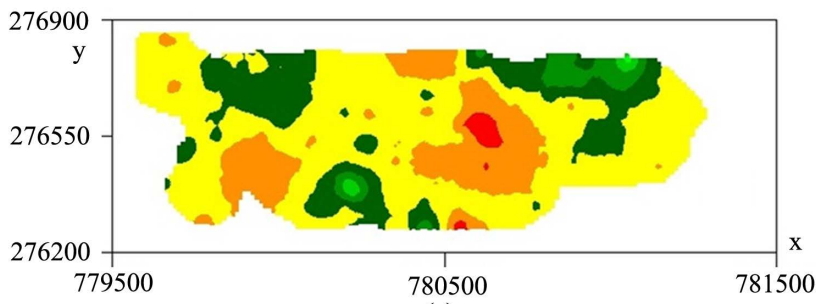

(a)

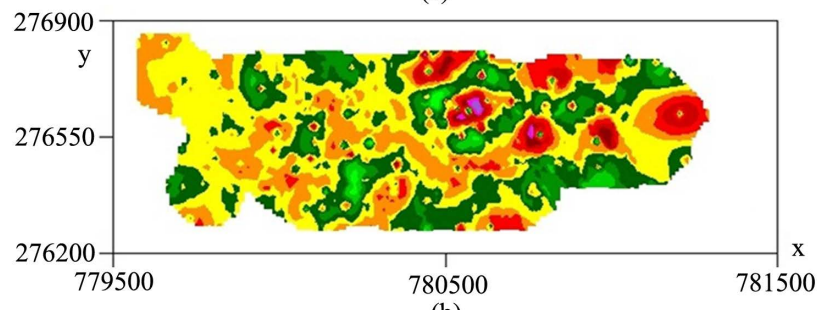

(b)

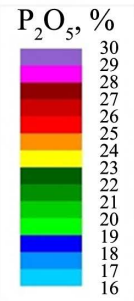

Figure 11. Kriging model showing $\mathrm{P}_{2} \mathrm{O}_{5} \%$ distribution for lower member of west Sebaiya where, (a) Ordinary Kriging model, (b) Cokriging model.

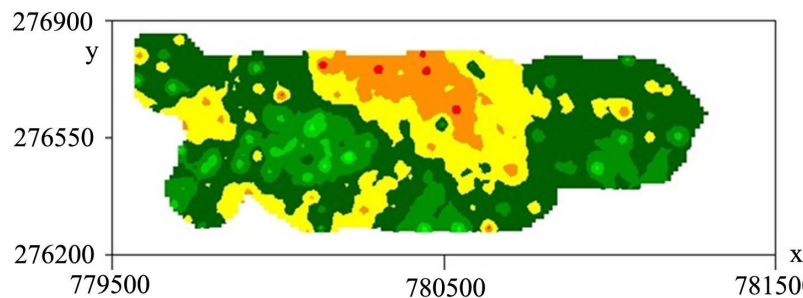

(a)
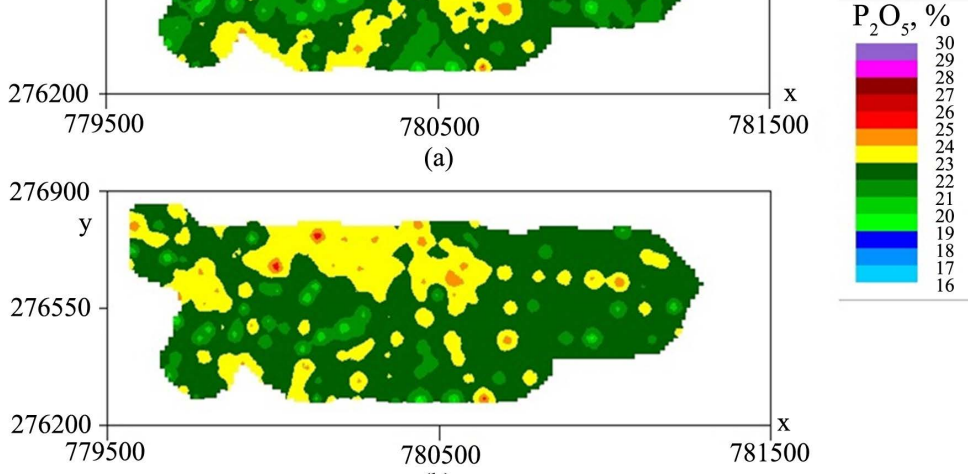

(b)

Figure 12. Kriging model showing $\mathrm{P}_{2} \mathrm{O}_{5} \%$ distribution for upper member of west Sebaiya where, (a) Ordinary Kriging model, (b) Cokriging model.

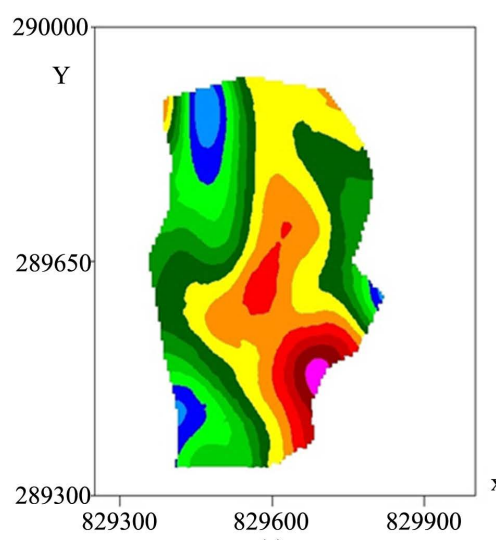

(a)

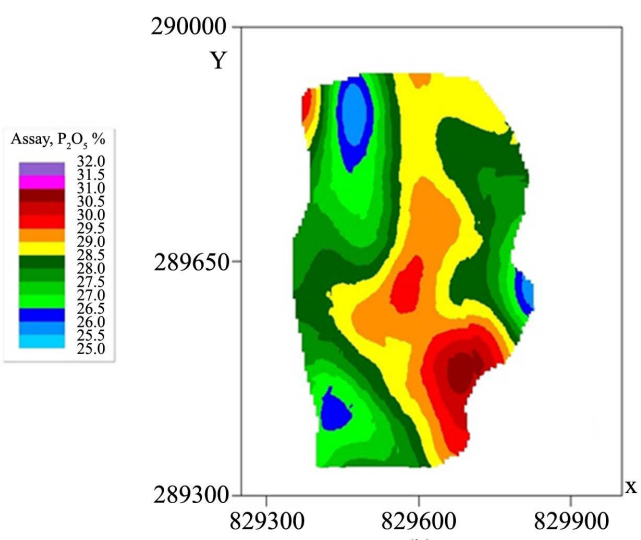

(b)

Figure 13. Kriging model showing $\mathrm{P}_{2} \mathrm{O}_{5} \%$ distribution for um tondoba mine in east Sebaiya where, (a) Ordinary Kriging model, (b) Cokriging model. 
Applying geostatistical techniques revealed different behavior of mineralization within the deposit as reflected by the different variogram parameters. The appearance of nugget effect on the variogram models for $\mathrm{P}_{2} \mathrm{O}_{5} \%$ at the lower member of Western Sebaiya, referred to short scale distance variability to give an attention to vertical variation due to possibility of presence of other elements within the deposits, which could be modeled too.

Results obtained from cokriging method were compared with those from ordinary kriging method which illustrated the clear differences in distributions of $\mathrm{P}_{2} \mathrm{O}_{5} \%$ in the deposits where it could be useful when planning the mine for production.

\section{Conflicts of Interest}

The authors declare no conflicts of interest regarding the publication of this paper.

\section{References}

[1] Abbady, A.G.E., Uosif, M.A.M. and El-Taher, A. (2005) Natural Radioactivity and Dose Assessment for Phosphate Rocks from Wadi El-Mashash and El-Mahamid Mines, Egypt. Journal of Environmental Radioactivity, 84, 65-78. https://doi.org/10.1016/j.jenvrad.2005.04.003

[2] Said, R. (1962) The Geology of Egypt. Elsevier, Amsterdam, Oxford, New York.

[3] Moharram, O., El-Ramly, M.F., Amer, A.F., Ivanov, S.S. and Gachechiladze, D.Z. (1970) Studies on Some Mineral Deposits of Egypt. Geological Survey of Egypt.

[4] Hermina, M.H. (1972) Review on the Phosphate Deposits of Egypt. 2nd Arab Conf. Mine, Res. Conf. Paper, 109-149.

[5] Ismael, A.F. (2003) Effect of Geological Setting on Geostatistical Evaluation of Ore Reserves. Master of Science in Mining, Al-Azhar University, Cairo, Egypt, 111 p.

[6] El-Nasr Mining Company (2010) Unpublished Technical Report about Mining Works Which Is Conducted in Elsebaiya, East Nile Valley, Egypt.

[7] Zidan, I.H. (2013) Evaluation of Phosphorite and Uranium in Lower Phosphorite Member, Duwi Formation at Kummer Area, South Esna, West Nile Valley, Egypt. Journal of Sedimentological Society of Egypt, 21, 143-154.

[8] Ahmadi, S.H. and Sedghamiz, A. (2008) Application and Evaluation of Kriging and Cokriging Methods on Groundwater Depth Mapping. Environmental Monitoring and Assessment, 138, 357-368. https://doi.org/10.1007/s10661-007-9803-2

[9] Crystal Johnson (2015) Using Kriging, Cokriging, and GIS to Visualize Fe and Mn in Groundwater, Electronic Theses and Dissertations. Paper 2498.

[10] Anon (2015) Geostatistics for the Environmental Sciences, Manual of software produced by Gamma Design Software, LLC Plainwell, Michigan 49080.

[11] Chang, Y.H., Scrimshaw, M.D., Emmerson, R.H.C. and Lester, J.N. (1998) Geostatistical Analysis of Sampling Uncertainty at the Tollesbury Managed Retreat Site in Blackwater Estuary, Essex, UK: Kriging and Cokriging Approach to Minimise Sampling Density. Science of the Total Environment, 221, 43-57. https://doi.org/10.1016/S0048-9697(98)00262-9

[12] Chien, Y.L., Lee, D.Y., Guo, H.Y. and Houng, K.H. (1997) Geostatistical Analysis of Soil Properties of Mid-West Taiwan Soils. Soil Science, 162, 291-297. https://doi.org/10.1097/00010694-199704000-00007 